\title{
Causes of Ozone Layer Depletion and Its Effects on Human: Review
}

\author{
Fakhra Anwar*, Fahad Nazir Chaudhry, Saiqa Nazeer, Noshila Zaman, Saba Azam \\ Department of Zoology, University of Gujrat, Hafiz Hayat Campus, Gujrat, Pakistan \\ Email: "Fakhra786zoologist@gmail.com
}

Received 12 October 2015; accepted 24 January 2016; published 27 January 2016

Copyright $@ 2016$ by authors and Scientific Research Publishing Inc.

This work is licensed under the Creative Commons Attribution International License (CC BY). http://creativecommons.org/licenses/by/4.0/

(c) (1) Open Access

\section{Abstract}

This study was conducted at University of Gujrat during 2014-2015 as a term paper for Master of Philosophy. The data regarding effect of ozone depletion on human was reviewed and compiled as a review paper from various published articles of international reputed journals, annual/environmental reports of recognized organization and e-books. The causes, mechanism and bio-effects of ozone layer depletion on humans were addressed. It is revealed that introduction of Chloroflourocarbons (CFCs) in the environment is the most rated cause of said depiction. Ozone depletion is allowing the UV radiation to earth surface. The exposure to these radiations is severely affecting all life forms on earth, especially the humans. Permanent or temporary blindness, skin cancer and immunity suppression are the main effects of these radiations reported by various researchers on humans. The prospects of ozone recovery are still undiscovered. The current situation of ozone depiction demands urgent remedial measures to protect lives on this earth.

\section{Keywords}

Ozone, Ozone Depletion, Chloroflourocarbons (CFCs), Ultra Violet (UV) Radiations, Bio-Effects

\section{Introduction}

Many of human activities are badly affecting the atmosphere. Ozone depletion is one of those examples [1]. Life is protected from UV rays by stratospheric ozone layer which acts as a shield or sun screen [2]. Approximately $90 \%$ ozone is present in stratosphere at the height of 10 to 17 kilometer and is called ozone layer while remaining $10 \%$ is present in troposphere [3]. Medium frequency UV radiations (200 $\mathrm{nm}$ to $315 \mathrm{~nm}$ ) are absorbed 97 to $99 \%$ by the ozone layer [4]. Ozone $\left(\mathrm{O}_{3}\right)$ is colourless just like oxygen $\left(\mathrm{O}_{2}\right)$ but it has very harsh odour. It is very rare as compared to oxygen. It is estimated that out of 10 million air molecules about 2 millions are of $\mathrm{O}_{2}$ and

"Corresponding author.

How to cite this paper: Anwar, F., Chaudhry, F.N., Nazeer, S., Zaman, N. and Azam, S. (2016) Causes of Ozone Layer Depletion and Its Effects on Human: Review. Atmospheric and Climate Sciences, 6, 129-134.

http://dx.doi.org/10.4236/acs.2016.61011 
only 3 are of ozone [5]. The process of ozone formation is called as photolysis. When the UV radiations from sun strike the $\mathrm{O}_{2}$ molecules, it causes splitting of $\mathrm{O}_{2}$. Oxygen molecules react with oxygen atoms in the upper atmosphere to form ozone. Stratospheric ozone is measured from the ground in units called "Dobson Unit" (D.U) [1]. Normal ozone concentration is between 300 - 350 D.U [5]. In our present study, we shall discuss how ozone layer depletion is affecting human health and we shall also discuss some recommendations to minimize ozone depletion and its adverse effects on human health.

\section{Ozone Layer}

The ozone layer is basically naturally occurring gas in the region of stratosphere where ozone particles are accumulated [2]. Ozone layer is also naturally broken down but there is a balance between its formation and natural depletion. As a result the total amount of ozone remains constant. But ozone layer thickness varies with altitude and seasonal change. Ozone concentration is highest between $19-23 \mathrm{~km}$ [6]. Most of ozone is formed at equator where there is maximum sunshine but with winds it travels at high altitude and get accumulated in stratosphere [1].

\section{Ozone Hole}

Ozone hole is created in the region where ozone layer has been depleted. The term "Ozone hole" is applied when the depletion level is below 200 Dobson Unit (D.U). Ozone holes are first discovered in Antarctica in 1970. Few years ago ozone holes are also discovered in arctic region. Since 2000 rate of ozone depletion is increasing 0.5 percent per year [7]. Due to depletion of Ozone UV rays are penetrating in troposphere and leading to more ozone formation in troposphere which is causing injurious effects on our health as ozone is toxic for our body [8].

\section{Causes of Ozone Depletion}

\subsection{Chlorofluorocarbons}

Ozone depletion occurs when the natural balance between the production and destruction of stratospheric ozone is disturbed. Although natural phenomenon can cause ozone depletion but human activities such as CFCs are now accepted as major cause of depletion [9]. All ozone depleting chemicals contain chlorine and bromine [10]. CFCs are highly volatile and non combustible so they are very quickly evaporated and can easily reach in stratosphere where ozone is present here they start depleting ozone molecules. These CFCs have also adverse affects on human health [11]. According to the chemical model for ozone destruction proposed about 20 years ago, the photolysis of $\mathrm{Cl}_{2} \mathrm{O}_{2}$ is key to ozone depletion reaction. But now atmospheric researchers studied that the rate of this reaction is not extremely high as it was thought previously so we can no longer say that CFCs are the main cause of ozone depletion [12].

\subsection{Unregulated Launches of Rockets}

Another major cause of large scale ozone depletion is Rocket launches. It has been studied that unregulated rocket launches can result in much more ozone depletion than CFCs. It is estimated that if rocket launches will be let unregulated then it would cause huge ozone loss by the year 2050 than the CFCs have done [1].

\subsection{Global Warming}

Global warming also leads to ozone layer depletion. Due to global warming and green house effect most of the heat is trapped in troposphere which is the layer below the stratosphere. As we all know ozone is present in stratosphere so heat don't reaches troposphere and it remain cold as recovery of ozone layer requires maximum sunlight and heat so it leads to depletion of ozone layer [1].

\subsection{Nitrogenous Compound}

Nitrogenous Compounds emitted by human activities in small amount like $\mathrm{NO}, \mathrm{N}_{2} \mathrm{O}$ and $\mathrm{NO}_{2}$ are considered to be greatly responsible for the depletion of ozone layer [13]. 


\section{Effects of Ozone Depletion}

Ozone depletion is affecting the human health and environment negatively, as it allows the penetration of UV radiations to reach the Earth. These radiations can cause severe diseases in humans such as skin cancer, eye damage and genetic mutations etc. [9]. Furthermore the ozone depletion is affecting the aquatic life, biogeochemical cycles, air quality and also contributing in Global warming but in this review paper our main focus is on the effects of ozone depletion on human health [1].

\subsection{Effects on Eyes}

The major cause of blindness in this world is cataracts. There would be $0.3 \%-0.6 \%$ increase in risk of cataract if there will be 1\% decrease in Ozone level [14]. Eye lens can be damaged by oxidative agents. Oxidative oxygen produced by UV radiation can severely damage eye lens and cornea of eye is also badly damaged by UV radiation [15]-[17]. Photokeratitis, cataract, blindness all are caused due to UV rays [18].

\subsection{Effects on Skin}

Exposure to UV radiations can cause skin cancer. UV radiations alter the structure of biomolecules and thus lead to different diseases [10] [19] Skin is the most often exposed part of body to UV radiations There are two types of skin cancer, Melanoma and Non-melanoma. Melanoma is most serious form of cancer and is often fatal, while non-melanoma is most common type and less fatal. Depletion of ozone layer leads to both Sun burn and skin cancer [20]. UV radiations are also responsible for breast cancer and leukemia [18].

Epidemiological studies of Melanoma indicate that the incidence of melanoma is increasing in those countries having high ratio of cases [21]-[23]. As UV radiations can penetrate more easily in thin skin so there is greater number of incidence is found in thin skinned people. It is found that the incidence of Melanoma is more in children than adults. The chance of incidence of melanoma is correlated with UV exposure furthermore the survival chance of melanoma is less in boys as compared to girls [24] [25]. As the intensity of radiation increases in summer so the risk of melanoma in thin skinned people is increased in summer and it is more in females as compared to males as their skin is thinner than males [26] [27].

There is considerable relationship between melanoma risk and intermittent sun exposure and sunburn history [28]. There is also a direct relationship between air travelling and melanoma incidence [29]. However the studies revealed that genetic factors contribute more for having melanoma disease than behavioral aspects [30]. The epidemiological studies of non melanoma skin carcinoma (NMSC) indicates that its risk is more in young females in lower limbs [16] [20] and sunbathing increases its risk five times in trunk region.

\subsection{Effects on Human Immunity}

Exposure to UV radiations can also result in suppression of immune response to skin cancer, infectious diseases and other antigens [1]. The immunosupression is due to changes in skin photoreceptors and antigen presenting cells that are brought by UV radiations [31]. More increase in depletion of ozone results in more decrease in immune system [10].

\subsection{DNA Damage and Lung Diseases}

Short exposure to UV-B radiations can cause the DNA damage because UV radiations can disturb biomolecules such as lipids, proteins and Nucliec acids. Due to UV-B radiations there would be cryptic transposable elements which may lead towards the mutations which is more dangerous than the immediate DNA damage [32]. Excessive UV-B radiation exposure results in the basal and squamous cells carcinomas. These types of cancers are induced due to transcriptional errors during DNA replication which are caused by changes in pyrimidine bases. The ultimate cause of this whole mechanism is found to be the prolonged exposure to UV radiations. It is estimated that there is increase of $2 \%$ of incidence of these cancers by $1 \%$ depletion of ozone layer [33]. Exposure to UV radiations equally affects lungs. Bronchitis, obstruction of lungs, Emphysema, asthma all can be resulted from UV radiations exposure [18].

\subsection{Effects of Hydrogen Peroxide on Human Health}

Due to stratospheric ozone layer depletion UV radiations are penetrating in earth atmosphere which result in the 
production of reduced oxygen. Highly reactive species like hydrogen peroxide is produced which has bad effects on human health. It is ideal photochemical maker due to its long life and stability [1] [34]. Hydrogen peroxide is toxicant and it pollutes drinking water especially in lakes and makes water toxic and unfit for drinking. IT alters redox chemistry of metals that are used by our body like iron copper and manganese [35].

\subsection{Effect of Food Shortage on Human Population}

Depletion of ozone layer is also causing the problem of food shortage to humans. UV radiations are disturbing developmental and physiological processes which is decreasing the productivity of crops. As humans are heavily dependent on crops for food so there is a great chance if depletion of ozone layer is not checked it may cause seriously shortage of food to humans [36]. Researches also show that UV radiations can also be used to enhance yield of crops by the use and application of phytohormones [37] [38].

\section{Conclusion and Recommendations}

Ozone layer is continuously depleting which is highly alarming situation of today. Chloroflourocarbons are major cause of ozone depletion. These substances should be banned or we should use their alternatives so that in future we can protect ourselves from the harmful effects of UV radiation.

Human eye and skin are the most exposed part of the body to these radiations. So there is high degree of incidence of blindness and skin cancer disease increasing day by day with the depletion of ozone layer so we should use sunglasses and full body clothes especially in summer when there is high intensity of sunlight so that we can protect our body from harmful UV radiations. We should also use sun block creams to our most exposed parts of body like face.

We should also don't consume water from lakes as it may contain high quantity of hydrogen peroxide which is toxic to our bodies, and we should consume water for drinking from clean water sources.

\section{References}

[1] Sivasakthivel, T. and Reddy, K.K.S.K. (2011) Ozone Layer Depletion and Its Effects: A Review. International Journal of Environmental Science and Development, 2, 30-32.

[2] United States Environmental Protection Agency (EPA) (2010) Ozone Layer Depletion 2010 Assessment.

[3] Gleason, K.L. (2008) Stratospheric Ozone: Monitoring and Research in NOAA. http://www.ozonelayer.noaa.gov/index.htm

[4] Albritton and Daniel (1998) What Should Be Done in a Science Assessment In Protecting the Ozone Layer: Lessons, Models, and Prospects.

[5] Alternative Fluorocarbons Environmental Acceptability Study (AFEAS), Washington DC, 1995.

[6] Morrisette and Peter M. (1995) The Evolution of Policy Responses to Stratospheric Ozone Depletion. Natural Resources Journal, 29, 796-797.

[7] Rozema, J., Boelen, P. and Blokker, P. (2005) Depletion of Stratospheric Ozone over the Antarctic and Arctic: Responses of Plants of Polar Terrestrial Ecosystems to Enhanced UV-B, an Overview. Environmental Pollution, 137, 428-442. http://dx.doi.org/10.1016/j.envpol.2005.01.048

[8] Fears, T.R., Bird, C.C., Guerry, D., Sagebiel, R.W., Gail, M.H., Elder, D.E., Halpern, A., Holly, E.A., Hartge, P. and Tucker, M.A. (2002) Average Midrange Ultraviolet Radiation Flux and Time Outdoors Predict Melanoma Risk. Cancer Research, 62, 3992-3996.

[9] Angell, J.K. and Korshover, J. (2005) Quasi-Biennial and Long-Term Fluctuations in Total Ozone. Monthly Weather Review, 101, 426-43.

[10] Andersen, S. and Sarma, M. (2002) Protecting the Ozone Layer. The United Nations History, Earthscan Publicatios Ltd., Virginia.

[11] Chlorofluorocarbons (CFCs) (2010) Health Information Summary. Environmental Fact Sheet. New Hampshire Department of Environmental Services.

[12] Schiermeier, Q. (2007) Chemists Poke Holes in Ozone Theory. Nature, 449, 382-383. http://dx.doi.org/10.1038/449382a

[13] Ravishankara, A.R., Daniel, J.S. and Portmann, R.W. (2009) Nitrous Oxide (N2O): The Dominant Ozone-Depleting Substance Emitted in the 21st Century. Science, 326, 123-125. http://dx.doi.org/10.1126/science.1176985 
[14] United Nations Environment Programme (1994) Environmental Effects of Ozone Depletion: 1994 Assessment. UNEP, Nairobi.

[15] Christenson, L.J., Borrowman, T.A., Vachon, C.M., et al. (2005) Incidence of Basal Cell and Squamous Cell Carcinomas in a Population Younger Than 40 Years. JAMA, 294, 681-690. http://dx.doi.org/10.1001/jama.294.6.681

[16] Eaton, J.W. (1995) UV-Mediated Cataractogenesis: A Radical Perspective. Documenta Ophthalmologica, 88, $233-242$.

[17] Lee, K.W., Meyer, N. and Ortwerth, B.J. (1999) Chromatographic Comparison of the UVA Sensitizers Present in Brunescent Cataracts and in Calf Lens Proteins Ascorbylated in Vitro. Experimental Eye Research, 69, 375-384. http://dx.doi.org/10.1006/exer.1999.0709

[18] Wargent, J.J. and Jordan, B.R. (2013) From Ozone Depletion to Agriculture: Understanding the Role of UV Radiation in Sustainable Crop Production. New Phytologist, 197, 1058-1076. http://dx.doi.org/10.1111/nph.12132

[19] Tian, J. and Juan, Y. (2009) Changes in Ultrastructure and Responses of Antioxidant Systems of Algae (Dunaliella salina) during Acclimation to Enhanced Ultraviolet-B Radiation. Journal of Photochemistry and Photobiology B: Biology, 97, 152-160. http://dx.doi.org/10.1016/j.jphotobiol.2009.09.003

[20] Pearce, M.S., Parker, L., Cotterill, S.J., Gordon, P.M. and Craft, A.W. (2003) Skin Cancer in Children and Young Adults: 28 Years' Experience from the Northern Region Young Person's Malignant Disease Registry, UK. Melanoma Research, 13, 421-426. http://dx.doi.org/10.1097/00008390-200308000-00013

[21] Marks, R. (2002) The Changing Incidence and Mortality of Melanoma in Australia. Recent Results in Cancer Research, 160, 113-121. http://dx.doi.org/10.1007/978-3-642-59410-6 15

[22] Stang, A., Pukkala, E., Sankila, R., Soderman, B. and Hakulinen, T. (2006) Time Trend Analysis of the Skin Melanoma Incidence of Finland from 1953 through 2003 including 16,414 Cases. International Journal of Cancer, 119, 380384. http://dx.doi.org/10.1002/ijc.21836

[23] Cayuela, A., Rodriguez-Dominguez, S., Lapetra-Peralta, J. and Conejo-Mir, J.S. (2005) Has Mortality from Malignant Melanoma Stopped Rising in Spain? Analysis of Trends between 1975 and 2001 . British Journal of Dermatology, 152, 997-1000. http://dx.doi.org/10.1111/j.1365-2133.2005.06517.x

[24] Strouse, J.J., Fears, T.R., Tucker, M.A. and Wayne, A.S. (2005) Pediatric Melanoma: Risk Factor and Survival Analysis of the Surveillance, Epidemiology and End Results Database. Journal of Clinical Oncology, 23, 4735-4741. http://dx.doi.org/10.1200/JCO.2005.02.899

[25] Ulmer, M.J., Tonita, J.M. and Hull, P.R. (2003) Trends in Invasive Cutaneous Melanoma in Saskatchewan 1970-1999. Journal of Cutaneous Medicine and Surgery, 7, 433-442. http://dx.doi.org/10.1007/s10227-003-0159-0

[26] Boniol, M., Armstrong, B.K. and Dore, J.F. (2006) Variation in Incidence and Fatality of Melanoma by Season of Diagnosis in New South Wales, Australia. Cancer Epidemiology, Biomarkers \& Prevention, 15, 524-526.

[27] Boniol, M., De Vries, E., Coebergh, J.W. and Dore, J.F. (2005) Seasonal Variation in the Occurrence of Cutaneous Melanoma in Europe: Influence of Latitude. An Analysis Using the EUROCARE Group of Registries. European Journal of Cancer, 41, 126-132. http://dx.doi.org/10.1016/j.ejca.2004.09.011

[28] Gandini, S., Sera, F., Cattaruzza, M.S., Pasquini, P., Picconi, O., Boyle, P. and Melchi, C.F. (2005) Meta-Analysis of Risk Factors for Cutaneous Melanoma: II. Sun Exposure. European Journal of Cancer, 41, 45-60. http://dx.doi.org/10.1016/j.ejca.2004.10.016

[29] Agredano, Y.Z., Chan, J.L., Kimball, R.C. and Kimball, A.B. (2006) Accessibility to Air Travel Correlates Strongly with Increasing Melanoma Incidence. Melanoma Research, 16, 77-81. http://dx.doi.org/10.1097/01.cmr.0000195696.50390.23

[30] Berwick, M. and Wiggins, C. (2006) The Current Epidemiology of Cutaneous Malignant Melanoma. Frontiers in Bioscience, 11, 1244-1254. http://dx.doi.org/10.2741/1877

[31] United Nations Environment Programme (2006) Environmental Effects of Ozone Depletion and Its Interaction with Climate Change: 2006 Assessment. UNEP, Nairobi.

[32] Shindell, D.T., Rind, D. and Lonergan, P. (1998) Increased Polar Stratospheric Ozone Losses and Delayed Eventual Recovery Owing to Increasing Greenhouse-Gas Concentration. Nature, 292, 589-592. http://dx.doi.org/10.1038/33385

[33] Strouse, J.J., Fears, T.R., Tucker, M.A. and Wayne, A.S. (2005) Pediatric Melanoma: Risk Factor and Survival Analysis of the Surveillance, Epidemiology and End Results Database. Journal of Clinical Oncology, 23, 4735-4741. http://dx.doi.org/10.1200/JCO.2005.02.899

[34] Miller, W.L. (1994) Recent Advances in the Photochemistry of Natural Dissolved Organic Matter. In: Helz, G.R., et al., Eds., Aquatic and Surface Photochemistry, Lewis Publishers, Boca Raton, 111-127.

[35] Miller, W.L. and Kester, D. (1994) Peroxide Variations in the Sargasso Sea. Marine Chemistry, 48, 17-29. http://dx.doi.org/10.1016/0304-4203(94)90059-0

[36] Newsham, K.K. and Robinson, S.A. (2009) Responses of Plants in Polar Regions to UV-B Exposure: A Meta-Analysis. 
Global Change Biology, 15, 2574-2589. http://dx.doi.org/10.1111/j.1365-2486.2009.01944.x

[37] Hulten, M., Pelser, M., Van Loon, L.C., Pieterse, C.M.J. and Ton, J. (2006) Costs and Benefits of Priming for Defence in Arabidopsis. Proceedings of the National Academy of Sciences of the United States of America, 103, 5602-5607. http://dx.doi.org/10.1073/pnas.0510213103

[38] Davies, W.J., Zhang, J., Yang, J. and Dodd, I.C. (2011) Novel Crop Science to Improve Yield and Resource Use Efficiency in Water-Limited Agriculture. The Journal of Agricultural Science, 149, 123-131. http://dx.doi.org/10.1017/S0021859610001115 